\title{
CORSiCA: a Mediterranean atmospheric and oceanographic observatory in Corsica within the framework of $\mathrm{HyMeX}$ and ChArMEx
}

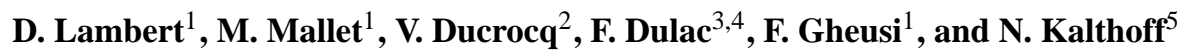 \\ ${ }^{1}$ Laboratoire d'Aérologie, Université de Toulouse, Toulouse, France \\ ${ }^{2}$ GAME-CNRM, CNRS and Météo-France, Toulouse, France \\ ${ }^{3}$ IPSL/Laboratoire des Sciences du Climat et de l'Environnement, UMR 8212 CEA-CNRSUVSQ, CEA Saclay, France \\ ${ }^{4}$ IPSL/Laboratoire Interuniversitaire des Systèmes Atmosphériques, UMR 7583 UPECUP7DD-CNRS, Créteil, France \\ ${ }^{5}$ Institute for Meteorology and Climate Research, Karlsruhe Institute of Technology (KIT), Karlsruhe, Germany
}

Received: 5 March 2010 - Revised: 12 May 2010 - Accepted: 7 October 2010 - Published: 14 January 2011

\begin{abstract}
CORSiCA (Corsican Observatory for Research and Studies on Climate and Atmosphere-ocean environment) is a project for a multi-site instrumented platform located in Corsica. It is dedicated to oceanographic and atmospheric studies in the framework of the Mediterranean projects HyMeX (Hydrological cycle in the Mediterranean Experiment) and ChArMEx (Chemistry-Aerosol Mediterranean Experiment). The observatory will provide the international scientific community with facilities for setting up a multiparametric observation platform in a region with little instrumentation at present. HyMeX and ChArMEx objectives and actions in Corsica are presented.
\end{abstract}

\section{Introduction}

The Mediterranean basin has quite a unique character that results both from geographic conditions and historical and societal developments. The region features an almost enclosed sea surrounded by very urbanized littorals and mountains in which numerous rivers have their sources. This results in many interactions and feedbacks among ocean-atmosphereland processes, which play a prominent role in the climate and ecosystems, and make the Mediterranean area a unique, highly coupled system. Furthermore, the Mediterranean region has been identified as one of the two main hot-spots of

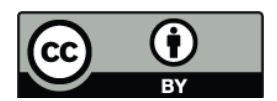

Correspondence to: D. Lambert (dominique.lambert@aero.obs-mip.fr) climate change, meaning that climate is especially responsive to global change in this area (Giorgi, 2006).

In the western Mediterranean basin (Fig. 1), Corsica is an $80 \mathrm{~km} \times 180 \mathrm{~km}$ island, on which the highest mountain reaches $2710 \mathrm{~m}$ and about twenty mountains are higher than $2000 \mathrm{~m}$. These mountains, which run roughly from NorthWest to South-East, are the highest of any Mediterranean island (Rome and Giorgetti, 2007). Furthermore, Corsica has the most rivers of any Mediterranean island. It is regularly affected by intense meteorological events: windstorms, heavy precipitation (Giorgetti et al., 1994), Saharan dust events, waves and coastal erosion, droughts, forest fires, and lightning. Moreover, it is influenced by different air masses of various origins allowing the study of both marine and continental (including anthropogenic pollution, biomass-burning, biogenic, and mineral dust) aerosols and of regional ozone pollution events in the NW Mediterranean. The long dry and sunny Mediterranean summer season that characterizes the regional climate and air mass recirculation in the western basin favours the accumulation of aerosol and ozone (Millan et al., 1997).

French research agencies have decided to support several projects within the framework of a large, coordinated, multidisciplinary programme focused on the Mediterranean region. This programme is called MISTRALS (Mediterranean Integrated STudies at Regional And Local Scales, http://www.dt.insu.cnrs.fr/c-med/c-med.php). It includes the HyMeX (Hydrological cycle in Mediterranean Experiment, http://www.hymex.org/) and ChArMEx (The ChemistryAerosol Mediterranean Experiment, http://charmex.lsce.ipsl. fr) projects. 
a

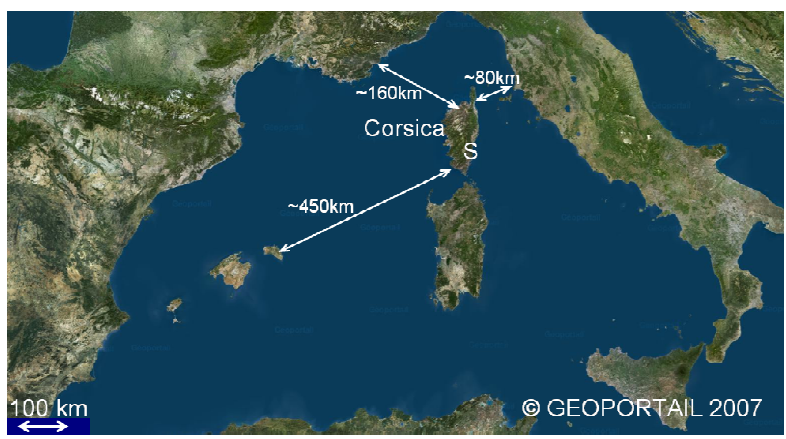

b

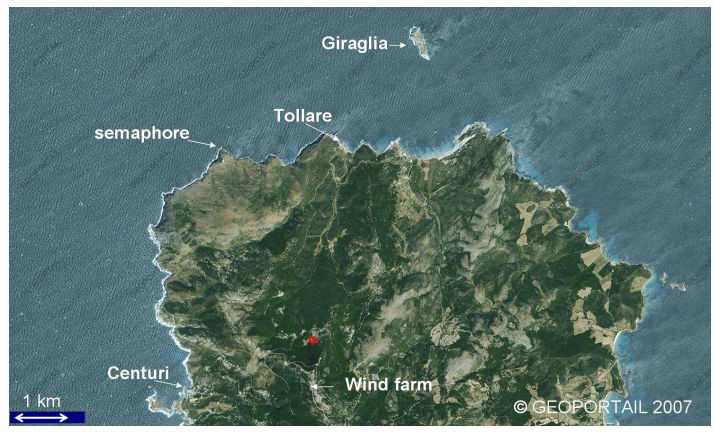

Fig. 1. (a) The Western Mediterranean basin. "S" indicates the military airport of Ventiseri-Solenzara. (b) The northern tip of Cap Corse. The red point indicates the main hamlet of Ersa. (C GEOPORTAIL 2007).

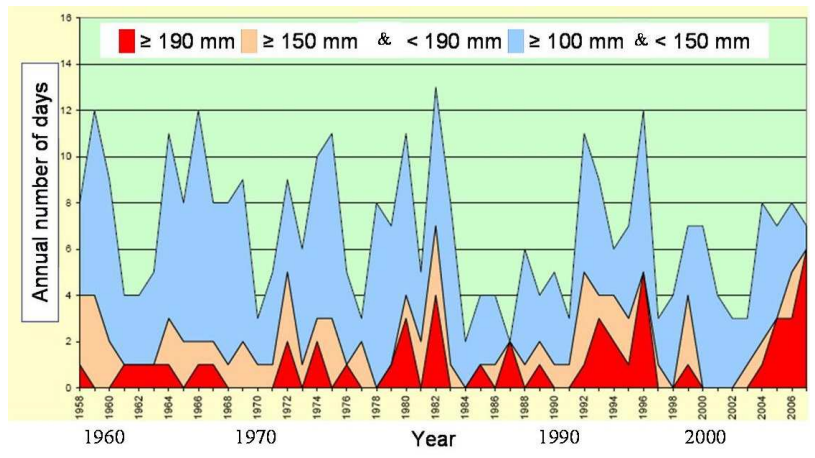

Fig. 2. Annual number of rainy days characterized by a $24 \mathrm{~h}$ total rainfall between $100 \mathrm{~mm}$ and $150 \mathrm{~mm}$ (in blue), between $150 \mathrm{~mm}$ and $190 \mathrm{~mm}$ (in beige) and above $190 \mathrm{~mm}$ (in red), from 1958 to 2007 in Corsica (courtesy of Météo-France).

In this framework, we propose to coordinate initiatives concerning measurements in Corsica to create a Mediterranean observatory that would give the scientific community facilities for setting up a multiparameter observation platform in a region where observations are sparse (when they exist at all). This observatory will be called CORSiCA for Corsican Observatory for Research and Studies on Climate and Atmosphere-ocean environment ${ }^{1}$. CORSiCA is not a project in parallel with HyMeX and ChArMEx but it is a structure which aims at facilitate exchanges between HyMeX and ChArMEx in Corsica on one hand and on the other hand between HyMeX/ChArMEx and local institutions in Corsica.

In Sects. 2 and 3 we present respectively the HyMeX and CharMEx objectives and actions in Corsica. Perspectives are given in the final section.

\footnotetext{
${ }^{1}$ In French: Centre d'Observation Régional pour la Surveillance du Climat et de l'environnement Atmosphérique et océanographique en Méditerranée occidentale
}

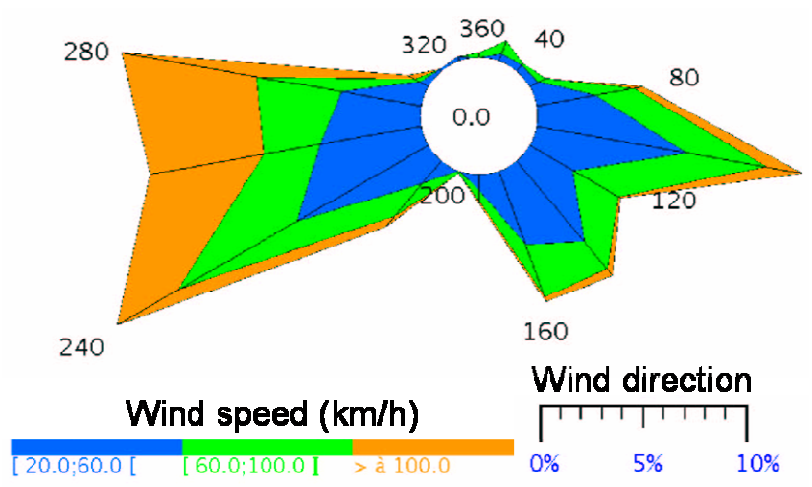

Fig. 3. Frequency of wind gusts at the Ersa semaphore (Cap Corse) according to direction from 1 January to 31 December 2007 (courtesy of Météo-France). Blue is for wind between $20 \mathrm{~km} / \mathrm{h}$ $(5.5 \mathrm{~m} / \mathrm{s})$ and $60 \mathrm{~km} / \mathrm{h}(16.7 \mathrm{~m} / \mathrm{s})$; green is for wind between $60 \mathrm{~km} / \mathrm{h}$ $(16.7 \mathrm{~m} / \mathrm{s})$ and $100 \mathrm{~km} / \mathrm{h}(27.8 \mathrm{~m} / \mathrm{s})$ and orange is for wind above $100 \mathrm{~km} / \mathrm{h}(27.8 \mathrm{~m} / \mathrm{s})$. The length of each segment is associated to the occurrence in each direction (given in degrees from North).

\section{HyMeX actions proposed in Corsica}

HyMeX aims at a better quantification and understanding of the hydrological cycle and related processes in the Mediterranean, with emphasis on high-impact weather events and the regional impacts of global change, including those on ecosystems and human activities.

Corsica is regularly affected by intense meteorological events: heavy precipitation and windstorms (Figs. 2 and 3), waves and coastal erosion, droughts, forest fires, and lightning. The Mediterranean climate is characterized by moist winters and dry summers. However, severe weather occurs mainly during the inter-seasons. Although the total annual precipitation ranges between 300 and $1000 \mathrm{~mm}$, the frequency of rainy days is under 100 per year. Half of the annual precipitation can fall locally in $24 \mathrm{~h}$ during heavy 
Table 1. Planned instrumentation for HyMeX in Corsica.

\begin{tabular}{|c|c|}
\hline HyMeX Instrument/network & Location \\
\hline Doppler wind lidar $1.6 \mu \mathrm{m}$ & $\begin{array}{l}\text { Tollare (1 lidar and microwave profiler temporary at Giraglia } \\
\text { island or at Corte) }\end{array}$ \\
\hline Doppler wind lidar $2.0 \mu \mathrm{m}$ & "1 \\
\hline Doppler wind lidar $1.54 \mu \mathrm{m}$ (wind cube) & " \\
\hline Sodar & " \\
\hline $\begin{array}{l}\text { Microwave temperature }(51-58 \mathrm{GHz}) \text { and humidity }(22- \\
31 \mathrm{GHz}) \text { radiometer }\end{array}$ & $\begin{array}{l}\text { Tollare (1 lidar and microwave profiler temporary at Giraglia } \\
\text { island or at Corte) }\end{array}$ \\
\hline Scanning cloud radar $(35 \mathrm{GHz})$ & Tollare \\
\hline K-band rain radar & " \\
\hline Ceilometer & " \\
\hline 2 cloud cameras & " \\
\hline Disdrometers & " \\
\hline $\begin{array}{l}1 \text { energy balance stations (including soil moisture measure- } \\
\text { ments at } 3 \text { depths) }\end{array}$ & "I \\
\hline 20 m high met. tower ( 7 levels: temperature, humidity, wind) & " \\
\hline Additional mobile towers & " \\
\hline Turbulence stations & " \\
\hline Scintillometer & " \\
\hline GPS station & " \\
\hline 1 radiosonde system & " \\
\hline 1 radiosonde system & Corte \\
\hline $\begin{array}{l}1 \text { energy balance stations (including soil moisture measure- } \\
\text { ments at } 3 \text { depths) }\end{array}$ & " \\
\hline Wind profiler: mini VHF & Ersa semaphore \\
\hline Wind profiler: UHF & " \\
\hline GPS station & $" 1$ \\
\hline Scintillometer (Giraglia) + Flux measurement & Giraglia island and Tollare \\
\hline Radar Poldirad (S-band) & western coast between Calvi and Cap Corse \\
\hline LINET Lightning detection & Ersa semaphore \\
\hline UHOH Scanning water vapour DIAL & Corte (and Tollare) \\
\hline UHOH Scanning Rotational Raman LIDAR & " \\
\hline X-Band Radar with disdrometer & " \\
\hline Sonic anemometer & Corte \\
\hline Aircraft base (potentially) & Ventiseri-Solenzara \\
\hline Operational Weather Radar ARAMIS & Aleria \\
\hline \multicolumn{2}{|l|}{ Météo-France instrumentation in Corsica } \\
\hline Dropsondes (from HALO or Falcon F20 aircraft) & \\
\hline
\end{tabular}

precipitation events. For example, Lambert and Argence, 2008, presented model simulations of the 14 September 2006 heavy rainfall episode in Corsica. The main synoptic ingredients leading to such heavy rainstorms in the northern part of the western Mediterranean basin are well known. In most cases, the two main ingredients are an upper tropospheric trough and a low-level supply of warm, wet air. In spite of this knowledge and of recent improvements in operational forecasting, numerical weather predictions regularly fail to reproduce the intensity and distribution of precipitation of heavy rainstorms at the mesoscale and local scale. Consequently, weather forecasters still have difficulties in predicting such precipitation events, particularly over the sea close to complex topography. Corsica is relevant as a sentinel observatory for the study of most of intense precipitation cases affecting continental south-eastern France and northern Italy. They are generally characterized by low-level warm and moist air mass transport from the south, channelled not only by the continental orography but also by the CorsicaSardinia islands ridge (Gheusi and Stein, 2003). In these situations, Corsica is located in the near upstream area of the flow finally leading to high precipitation events.

Corsica is also relevant for the study of cyclogeneses which often occur in the lee of the Alps (Speranza et al., 1985; Buzzi and Speranza, 1986) and subsequent high impact weather over the Ligurian Sea, the most cyclogenetic area of the western Mediterranean basin (Campins et al., 2006). At the most northerly and southerly points of Corsica 
Table 2. Planned instrumentation for ChArMEx in Corsica. This instrumentation will be located at Ersa except for one solar photometer and transmitter beacon that will be located in Pertusato semaphore (Bonifacio).

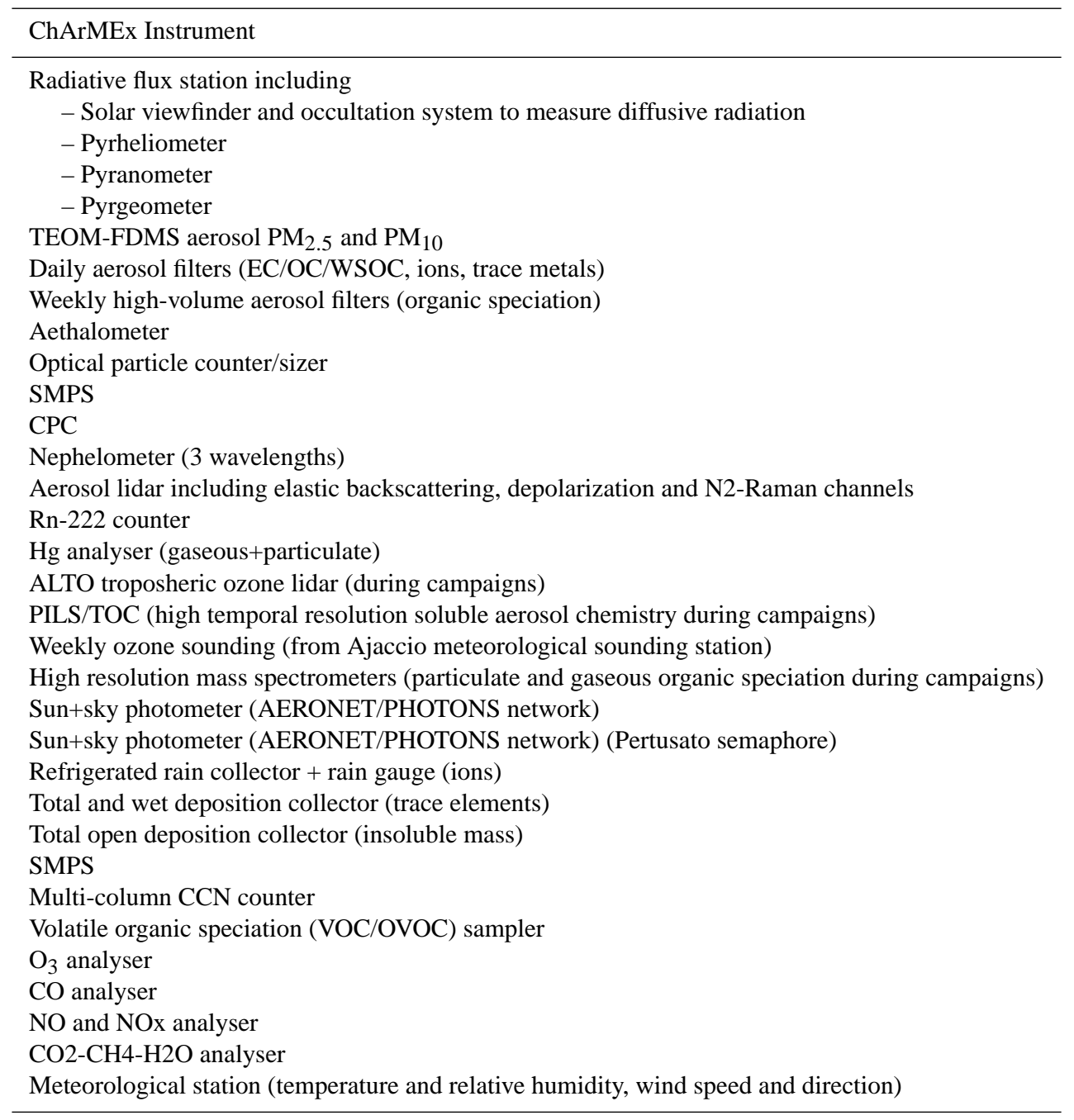

and where the valleys open out (Venturi effect), wind can be very strong. These windstorm events are frequent (78 days with wind gusts greater than $28 \mathrm{~m} / \mathrm{s}$ in 2007 at the Ersa semaphore at the northern tip of Cap Corse, Fig. 3). The Libeccio wind (westerly - south westerly) is the most frequent (Zecchetto and Cappa, 2001). For example, winds of over $28 \mathrm{~m} / \mathrm{s}$ occurred $21.4 \%$ of the time during 2007. The anemometers regularly stall as speeds reach $60 \mathrm{~m} / \mathrm{s}$.

Its geographical situation would allow Corsica to play the role of a "sentry", not yet exploited for these high precipitation and cyclogenesis events. At present, for meteorology, Corsica is instrumented with conventional weather stations operated by Météo-France. To complete this operational instrumentation, several international initiatives have emerged around measurements in Corsica in the framework of HyMeX:
- improvement of the existing data network with groundbased conventional weather stations and radiosounding stations;

- deployment of UHF and VHF wind profilers;

- deployment of a scintillometer;

- deployment of Doppler wind lidars, sodar radiometer, radars, ceilometers, disdrometers, energy and turbulence stations;

- deployment of a scanning water vapour DIAL and a scanning Rotational Raman LIDAR;

- deployment of an additional rain radar;

- installation of a ground-GPS receiver for moisture measurement; 
- thunderstorm and lightning activity studies;

- observation of Transient Luminous Events associated with thunderstorms;

- studies of high impact weather events;

- coastal oceanographic modelling and measurements;

- forest fire studies.

On the one hand, the instrumentation deployment and specific studies will contribute to document the upstream flow during extreme rainfall affecting South of France and North of Italy. On the other hand, they will significantly increase the local instrumentation which will give a great opportunity to study specific local atmospheric characteristics for a Mediterranean mountainous island. Table 1 presents the instrumentation that is expected to be deployed in Corsica for HyMeX. For Special Observation Periods (SOP), this approach has already been followed during previous experiments like for instance COPS (Convective and Orographically-induced Precipitation Study) which was devoted to the study of convection in Southern Germany and Eastern France in summer 2007 (Wulfmeyer et al., 2008; Kalthoff et al., 2009; Kottmeier et al., 2008).

\section{ChArMEx actions proposed in Corsica}

ChArMEx is a regional project on tropospheric chemistry and aerosols, which proposes an integrated modelling and observational approach to study budgets of species, chemical and dynamic processes, intense events, trends, and impacts on air quality, radiation and regional climate, and together with MERMEx (Marine Ecosystem Response Mediterranean Experiment; https://mermex.com.univ-mrs. fr) on marine ecosystems.

Corsica is located in the oligotrophic zone of the western Mediterranean basin enabling the impact of atmospheric deposition on primary production to be studied (Guieu et al., 2010). It is influenced by different air masses from various origins impacted by long-range transported anthropogenic pollution, biomass burning and natural emissions (Bergametti et al., 1992) and is well located for the monitoring of long-term changes in the background atmospheric environment of the western Mediterranean (Sauvage et al., 2007).

Due to the presence of various aerosol types over the Mediterranean region, such as mineral dust particles (mostly transported from the Saharan-Libyan deserts), anthropogenic aerosols, and also biomass burning particles from forest fires and marine aerosols, atmospheric particles are likely to have a significant impact on the regional climate and on the hydrological cycle over the Mediterranean basin. In parallel, because of the high deposition fluxes of desert dust and anthropogenic aerosols, atmospheric inputs impact the marine cycles of several chemical elements in the Mediterranean environment and could impact the regional marine ecosystem. Unlike most continental coastal stations, Cap Corse, the northern tip of Corsica Island, and especially the area of the village of Ersa (Fig. 1), is a remote site hardly affected by local anthropogenic activities where high aerosol episodes due to long-range transport of aerosol from southern Europe or Africa can be monitored (Figs. 4 and 5).

In spite of high concentrations of ozone and aerosols during the summer, permanent observations of gas and aerosols in the background troposphere are sparse in both space and time over the western Mediterranean basin. In that sense, a Mediterranean observatory in Corsica should be of great interest for investigating various scientific questions related to aerosols and trace gases over the Mediterranean basin. Several initiatives have emerged around measurements in Corsica in the framework of ChArMEx:

- characterization of aerosol chemical, physical and optical (both shortwave and longwave) properties and their vertical profiles;

- impacts of aerosols and trace gases on the radiation budget (both shortwave and longwave);

- monitoring of reactive gas species (Ozone, $\mathrm{NO}_{\mathrm{x}}, \ldots$ ) and greenhouse gases $\left(\mathrm{CO}_{2}, \mathrm{CH}_{4}\right)$;

- study of the mixing state of polluted, biomass burning and mineral dust aerosols;

- air quality and dynamic processes: import-export budgets;

- chemical processes: secondary matter formation;

- deposition measurements: Fe, P, Hg inputs and particulate mass flux (Saharan dust particles).

Table 2 presents the instrumentation that is expected to be deployed in Corsica for ChArMEx enhanced period of observations (EOP, 2011-2013) that includes intensive campaigns. Most of the instrumental set-up is planned to be integrated into long term environmental monitoring networks (EMEP, GAW, EARLINET, MOOSE, ICOS...).

\section{Conclusions}

In the western Mediterranean basin, Corsica Island occupies a strategic position for oceanographic and atmospheric studies in the framework of the Mediterranean projects HyMeX and ChArMEx. A multi-site instrumented platform located on this island has been presented. The project is called CORSiCA (Corsican Observatory for Research and Studies on Climate and Atmosphere-ocean environment). Several measurement sites are planned in various places in Corsica but the main site gathering the largest panel of instruments will be located at the northern tip of the island (Cap Corse). This 


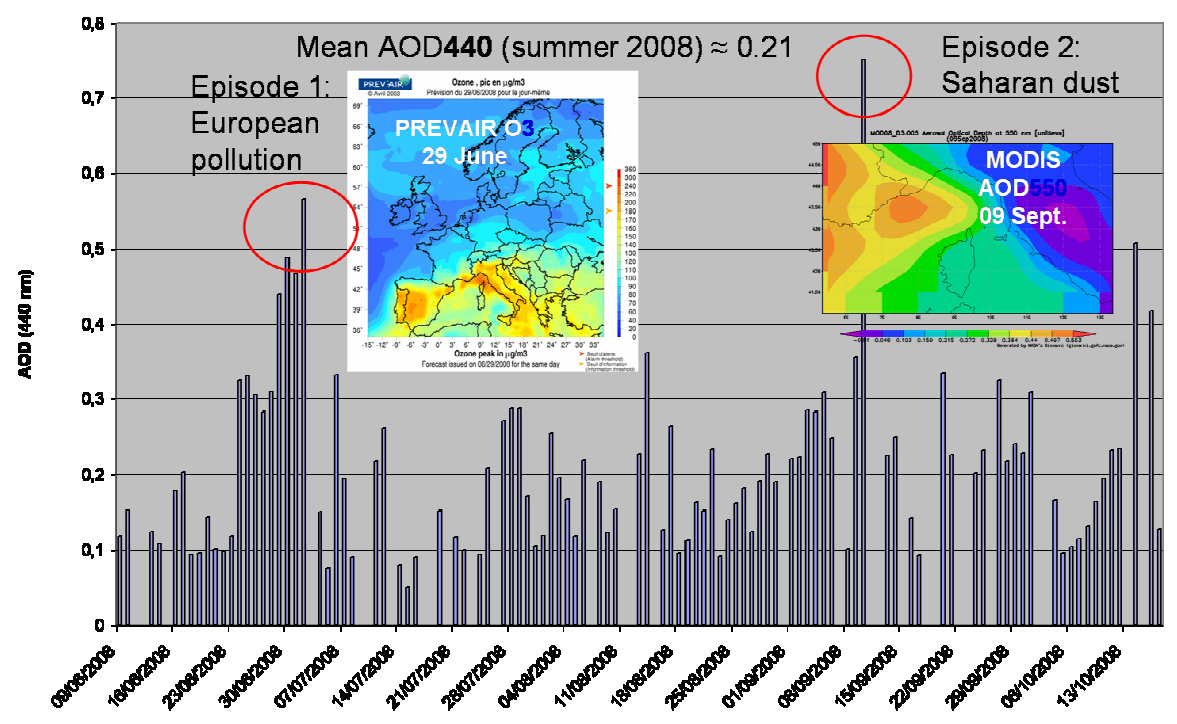

Fig. 4. Aerosol optical depth (AOD) at $440 \mathrm{~nm}$ measured near the semaphore of Ersa (Fig. 5) at an altitude of $80 \mathrm{~m}$ above mean sea level using a sun-photometer of the AERONET/PHOTONS network (http://aeronet.gsfc.nasa.gov/cgi-bin/type_one_station_opera_v2_new?site= Ersa\&nachal=2\&level=1\&place_code=10), showing two different high-aerosol episodes. Prevair web site: http://www.prevair.org/; Modis web site: http://modis.gsfc.nasa.gov/.
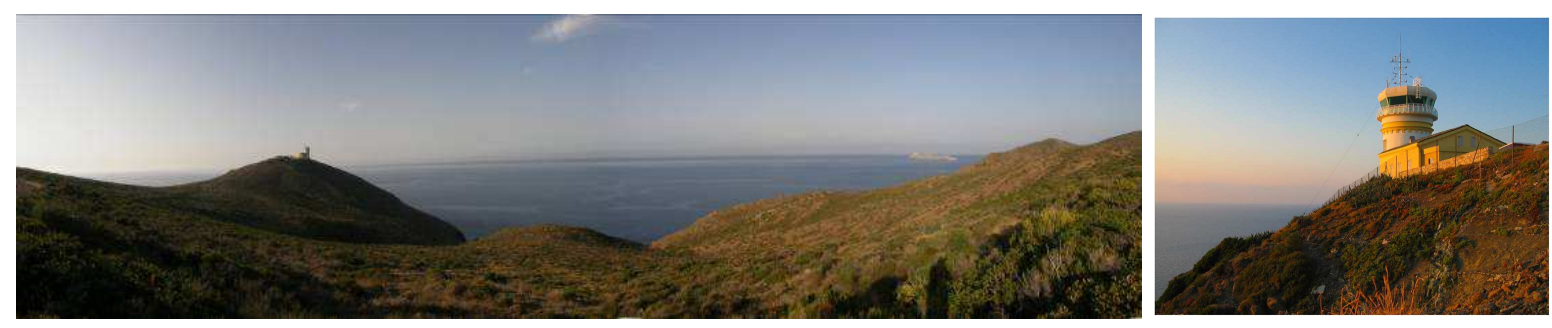

Fig. 5. The Cap Corse Semaphore in Ersa (Lat: $43^{\circ} 00^{\prime} 19^{\prime \prime}$ - Long: $09^{\circ} 21^{\prime} 30^{\prime \prime}$ ).

area (Fig. 1) is relevant for many reasons: it is open to the Ligurian Sea and is not impacted by local and regional anthropogenic inputs. In the village of Ersa, five very closed (Fig. 1b) sites are particularly interesting: the Semaphore $d u$ Cap Corse (Fig. 5) belonging to the French Navy, the wind farm site at $600 \mathrm{~m}$ in altitude, the Tollare site and Giraglia Island.

Contacts and partnerships have been established with local partners in Corsica: OEC (the Corsica environmental office), as a regional co-funding agency of the CORSiCA observatory, the University of Corsica, Qualitair Corse (local French air quality agency) and STARESO (Station de Recherches Sous-marines et Océanographiques), an oceanographic station located in Corsica.

CORSiCA will operate for the HyMEx and ChArMEx Long Observation Period, Enhanced Observation Period and Special Observation Periods (SOP). The HyMeX and ChArMEx projects anticipate locating an operations centre and aircraft base in Corsica during the SOP in 2012-2014.
In addition, this observatory will also be interesting for the MERMEx experiment (Marine Ecosystems Response in the Mediterranean Experiment). Furthermore, it will be supported by the MOOSE network (Mediterranean Ocean Observing System on Environment) to maintain long-term atmospheric observation of key parameters on this site.

To conclude, updated information dedicated to the CORSiCA observatory can be found on the web: http://www. aero.obs-mip.fr/spip.php?article658 and all atmospheric and oceanographic initiatives in Corsica are welcome to join the project.

Acknowledgements. The French Navy staff of the semaphore and the Ersa mayor are especially acknowledged for making possible early aerosol and ozone monitoring at the semaphore of Ersa (http://charmex.lsce.ipsl.fr/index.php/data). CNES, INSU and OMP/LA contributed to the funding of AERONET/PHOTONS sun photometer data. INSU, ADEME, Météo-France and CEA are acknowledged for funding support to new equipment that will be installed in early 2011. The authors thank their colleagues 
J.-H. Balbi, M.-P. Battesti, G. Bergametti, C. Bruno, B. Campistron, P. Chazette, P. Coddeville, S. Coquillat, U. Corsmeier, E. Defer, K. Desboeufs, P. Drobinski (co-coordinator of HyMeX), J.-B. Filippi, L. Gomes, C. Kottmeier, B. Laurent, P. Lejeune, R. Losno, M.-D. Loye, J. Nicolas, G. Notton, C. Paoli, J.-P. Rambaud, M. Ramonet, F. Sad, J. L. Savelli, J. Sciare, X. Silvani, S. Soula, V. Thouret for participating in the launching of the CORSiCA project.

Edited by: R. Deidda

Reviewed by: one anonymous referee

\section{References}

Bergametti, G., Remoudaki, E., Losno, R., Steiner, E., Chatenet, B. and Buat-Mnard, P.: Source, transport and deposition of atmospheric phosphorus over the northwestern Mediterranean, J. Atmos. Chem., 14, 501-513, 1992.

Buzzi, A. and Speranza, A.: A theory of deep cyclogenesis in the lee of the Alps. Part II: Topographic slope and height, J. Atmos. Sci., 43, 2826-2837, 1986.

Campins, J., Jansa, A., and Genoves, A.: Three-dimensional structure of western Mediterranean cyclones, Int. J. Climatol., 26, 323-343, 2006.

Giorgi, F.: Climate change hot-spots, Geophys. Res. Lett., 33, L08707, doi:10.1029/2006GL025734, 2006.

Giorgetti, J.-P., Jacq, V., Jourdan, R., Palauqui, J.-P., Rivrain, J.-C., Boeri, F., and Gauthier, A.: Les pluies diluviennes et les inondations des 31 octobre et du 1 novembre 1993 en Corse; étude descriptive, La Météorologie, 6, 9-30, 1994.

Gheusi, F. and Stein, J.: Small-scale rainfall mechanisms for an idealized convective southerly flow over the Alps, Q. J. R. Meteorol. Soc., 129, 1819-1840, 2003.

Guieu, C., Dulac, F., Desboeufs, K., Wagener, T., Pulido-Villena, E., Grisoni, J.-M., Louis, F., Ridame, C., Blain, S., Brunet, C., Bon Nguyen, E., Tran, S., Labiadh, M., and Dominici, J.M.: Large clean mesocosms and simulated dust deposition: a new methodology to investigate responses of marine oligotrophic ecosystems to atmospheric inputs, Biogeosci., 7, 2765-2784, 2010 .
Kalthoff, N., Adler, B., Barthlott, C., Corsmeier, U., Mobbs, S., Crewell, S., Traumner, K., Kottmeier, C., Wieser, A., Smith, V., and Di Girolamo, P.: The impact of convergence zones on the initiation of deep convection: A case study from COPS, Atmos. Res., 93, 680-694, 2009.

Kottmeier, Ch., Kalthoff, N., Barthlott, Ch., Corsmeier, U., et. al.: Mechanisms initiating deep convection over complex terrain during COPS, Meteorol. Z., 17 (6), 931-948, DOI:10.1127/09412948/2008/0348, 2008.

Lambert, D. and Argence, S.: Preliminary study of an intense rainfall episode in Corsica, 14 September 2006, Adv. Geosci., 16, 125-129, 2008, http://www.adv-geosci.net/16/125/2008/.

Millan, M., Salvador, R., Mantilla, E., and Kallos, G.: Photooxidant dynamics in the Mediterranean basin in summer: results from European research projects, Journal of Geophysical Research 102, 8811-8823, 1997.

Rome, S. and Giorgetti, J.-P.: La montagne corse et ses caractéristiques climatiques, La Météorologie, 59, 39-50, 2007.

Sauvage, B., Martin, R.V., van Donkelaar, A., Liu, X., Chance, K., Jaegl, L., Palmer, P.I., Wu, S., and Fu, T.-M.: Remote sensed and in situ constraints on processes affecting tropical ozone, Atmos. Chem. Phys., 7, 815-838, 2007, http://www.atmos-chem-phys.net/7/815/2007/.

Speranza, A., Buzzi, A., Trevisan, A., and Malguzzi, P.: A theory of deep cyclogenesis in the lee of the Alps. Part I: Modification of baroclinic instability by localized topography, J. Atmos. Sci., 42, 1521-1535, 1985.

Wulfmeyer, V., Behrendt, A., Bauer, H.-S., Kottmeier, C., Corsmeier, U., Blyth, A., Craig, G., Schumann, U., Hagen, M., Crewell, S., Di Girolamo, P., Flamant, C., Miller, M., Montani, A., Mobbs, S., Richard, E., Rotach, M. W., Arpagaus, M., Russchenberg, H., Schlussel, P., Konig, M., Gartner, V., Steinacker, R., Dorninger, M., Turner, D. D., Weckwerth, T., Hense, A., and Simmer, C.: The Convective and Orographically induced Precipitation Study. A research and development project of the World Weather Research Program for improving quantitative precipitation forecasting in low-mountain regions, B. Am. Meteorol. Soc., 89, 1477-1486, 2008.

Zecchetto, S. and Cappa, C.: The spatial structure of the Mediterranean Sea winds revealed by ERS-1 scatterometer, Int. J. Remote Sens., 22, 45-70, 2001. 